\title{
PAYING THE CONSEQUENCES
}

\section{Michael McCord, Solicitor of the Supreme Court}

Clients who are on the receiving end of a breach of contract claim invariably ask what damages they will be liable to pay if the breach is established. The answer is that a person who is in breach of contract is liable for whatever damage flows directly or obviously from the breach, and also for any further damage which was within the reasonable contemplation of that party when the contract was made. But what the courts have regarded as so called "direct loss" may surprise many ordinary business people.

Take the example of the tradesman who deals in spare parts for machinery in the manufacturing industry. He is contacted by a factory owner who tells him that a machine in the factory has broken down and that a spare part is required in order to get the machine working again. The tradesman delivers the spare part but it turns out to be defective, the machine will not work, and another spare part is required. The tradesman replaces the defective part with a good part free of charge. The price the factory owner paid for the defective part is clearly "direct loss" for which he has been compensated.

But what if the time taken between the supply of the defective part and supply of the replacement part is a day or so and in this time the factory owner's machine is forced to lie idle. Suppose the factory owner can show that the down time suffered in this period has resulted in a loss of production and consequently a loss of profit. Is he entitled to recover this loss of profit as damages from the tradesman for breach of contract? And is this loss of profit "direct loss" or "consequential loss"? The distinction, as we shall see later, can be crucial.

The rule of the common law is that where a party sustains a loss by reason of a breach of contract, he is, so far as money can do it, to be placed in the same situation, with respect to damages, as if the contract had been performed: Robinson $v$ Harman. ${ }^{\mathbf{1}}$ In the example given above the factory owner would argue that had the tradesman not, in breach of contract, supplied him with a defective spare part, his machine would not have been lying idle for the day or so it took for a replacement to be found. Instead it would have been at full productivity and the factory owner would not have suffered the loss of profit.

Not all loss, however, which flows from a breach of contract, is recoverable. The victim of a breach of contract cannot recover loss which is too "remote". This rule was established in the seminal case of Hadley $\mathrm{v}$ Baxendale in which Alderson B formulated what has since been referred to as a two limb test:

"the damages should be such as may fairly and reasonably be considered either arising naturally, that is, according to the usual course of things, from such breach of contract (limb 1) or such as may reasonably be supposed to have been in the

1 [1848] 1 Ex 850. 
contemplation of both parties at the time they made the contract as the probable result of the breach (limb 2)." 2

Applying the test to the situation described earlier the factory owner would no doubt consider that if he has ordered a spare part for his machine, and the part is defective, then it is perfectly natural and obvious that the loss he will suffer is not just the money he has spent on the defective part but also any money he loses due to the machine being out of production until the defective spare part is replaced. Furthermore the tradesman knew, at the time the order was placed, that the part was required in order to make the machine work again.

In this scenario (hypothetical - but all too common in practice) the factory owner would, it is submitted, be entitled to recover his lost profit from the tradesman under either limb of the rule in Hadley $\mathrm{v}$ Baxendale (subject of course to the requirement that the factory owner must have taken all reasonable steps to mitigate his loss).

It is to avoid this liability for loss of profit that many tradesmen and suppliers prepare standard terms and conditions seeking to limit or exclude such liability. Such exclusion clauses come in all sorts of guises but one form of words which has caused some difficulty is where the supplier seeks to exclude or limit liability for "consequential loss". Many ordinary business people would think that if they include a term in their contract saying, for example:

"The supplier agrees to supply a product of satisfactory quality which is fit for its purpose. If the supplier breaches this clause the supplier agrees to pay to the customer the price paid by the customer for the product however under no circumstances will the supplier be liable for consequential loss"

this means that the supplier is not liable for any loss of profit if the product he supplies turns out to be defective. Had the tradesman in the hypothetical scenario described earlier discovered such a clause in his contract he might well have felt encouraged toward the belief that he could defeat the factory owner's claim for damages for loss of profit.

A very similar question, however, was raised in the recent case of British Sugar Plc v NEI Power Projects Limited. ${ }^{3}$

In British Sugar the plaintiff (British Sugar) engaged the defendant (NEI Power) to design, supply, deliver, test and commission electrical equipment. The negotiations between the parties resulted in a contract which included a term which stated:

"the Seller will be liable for any loss, damage, cost or expense incurred by the Purchaser arising from the supply by the Seller of any such faulty goods or materials or any goods or materials not being suitable for the purposes for which they are required save that the Seller's liability for consequential loss is limited to the value of the contract."

2 [1854] 9 Ex 341.

3 [1997] 87 BLR 42. 
The contract price was about $£ 106,585.00$. The plaintiff alleged that the equipment was poorly designed and badly installed, and that this resulted in breakdowns in the power supply. The plaintiff alleged that it had suffered damages of over $£ 5$ million, consisting mainly of increased production costs and loss of profits due to the breakdown. A preliminary issue was tried by Alliot $\mathrm{J}$, who held that words seeking to place a limitation on liability for damages in relation to "consequential loss", did not apply to the loss suffered by the plaintiff which he held was loss flowing directly and naturally from the breach. The defendant appealed to the Court of Appeal.

The defendant argued that any reasonable businessman would understand that loss of profits would be "consequential loss" and submitted that it was important, in the context of a commercial contract, to ascertain what reasonable businessmen would have intended when interpreting the meaning of a contractual term. In support of this argument the defendant relied on a passage in McGregor On Damages which states:

“. . . in contract, where the pecuniary losses are nearly ubiquitous, another distinction is taken and built upon. This is the useful and important division between normal and consequential losses. The normal loss is that loss which every plaintiff in a like situation will suffer, the consequential loss is that loss which is special to the circumstances of the particular plaintiff. In contract the normal loss can generally be stated as the market value of the property, money or services that the plaintiff should have received under the contract less either the market value of what he does receive or the market value of what he would have transferred but for the breach. The consequential losses are anything beyond this normal measure, such as profits lost or expenses incurred through the breach, and are recoverable if not too remote." 4

The plaintiff relied primarily on two Court of Appeal decisions: Millars Machinery v David Way ${ }^{5}$ and Croudace Construction Limited v Cawoods Concrete Products Limited ${ }^{6}$ and also on an intervening decision at first instance of Saint Line Limited $v$ Richardsons Westgarth \& Co Limited. ${ }^{7}$ All three cases concerned interpretations of the word "consequential" in the context of contracts which contained clauses limiting liability for "consequential" loss or "consequential" damages. In all three cases the court held that consequential loss was something other than loss which flowed directly and naturally from the breach.

In the Saint Line case Atkinson J explained the position as follows:

"What does one mean by 'direct damage'? Direct damage is that which flows naturally from the breach without other intervening causes and independently of special circumstances, while indirect damage does not so flow. The breach certainly has brought it about, but only because of some supervening

\footnotetext{
4 McGregor on Damages (15th edn) paras 25-27.

5 [1935] 40 Com Cas 204.

6 [1978] 2 Lloyds Rep 55.

7 [1940] 2 KB 99, at 103-104.
} 
event or some special circumstances. . . In my judgment the words 'indirect or consequential' do not exclude liability for damages which are the direct and natural result of breaches complained of."

The Court of Appeal in British Sugar had no difficulty following this line of authority. Waller LJ said:

"Both the Millar case and the Croudace case were construing the word 'consequential' in a very similar context to that which appears in this case. With Court of Appeal authority construing the phrase in a very similar context, and another Court of Appeal saying that the view previously expressed as binding in yet another similar context, it would take some radical difference in language or a radical difference in context to persuade yet a further Court of Appeal not to construe the phrase the same way."8

Tellingly Waller LJ also said:

"Once a phrase has been authoritatively construed by a court in a very similar context to that which exists in the case in point, it seems to me that a reasonable businessman must more naturally be taken to be having the intention that the phrase should bear that same meaning as construed in the case in point. It would again take very clear words to allow a court to construe the phrase differently." 9

The upshot was that on a true construction of the contract the court held the parties had simply agreed to limit the defendant's liability for loss and damage not directly and naturally resulting from the defendant's breach of contract to an amount equal to the value of the contract. This construction left the defendant to answer the claim for $£ 5$ million $^{\mathbf{1 0}}$ as opposed to a claim limited to $£ 106,585$.

The case raises a number of interesting questions. If loss of profit is not "consequential loss" what is? It would seem that "consequential loss" must mean loss which is indirect or which, though caused by the breach of contract, is also the result of other supervening events unconnected with the breach. In Saint Line Atkinson J referred to loss brought about because of some special circumstances. If this is the case however such loss is surely not recoverable under the rule in Hadley v_Baxendale because it neither (a) flows directly from the breach nor (b) was within the reasonable contemplation of the parties at the time they made the contract. In other words, regardless of whether there is a contractual term excluding or limiting liability for "consequential loss", such loss, as defined by the Court of Appeal, is likely to be unrecoverable under the rule in Hadley v Baxendale anyway.

The Court of Appeal's definition of "consequential loss" is also, in certain respects, illogical. The Shorter Oxford English Dictionary definition of the

8 [1997] 87 BLR 42, at 50.

9 Ibid.

10 The issue here being whether this loss (or some of it) was direct and natural. 
word "consequential" is "following, especially as an effect, immediate or eventual or as a logical inference". Logically everything which follows as a result of a certain event is consequent upon that event. Where a breach of contract causes loss that loss is, as a matter of logic, consequential, whether it is a direct or indirect result of the breach. The dictionary definition would therefore extend to literally all damages suffered as a result of a breach of contract because in the ordinary English sense all loss is consequential in that it follows logically from the breach.

The British Sugar case highlights how important it is for business people to glean an understanding of what is meant, in the legal sense, by terms which are included in their standard terms and conditions. The case serves as a salutary reminder that in legal documentation terms will not necessarily bear their dictionary meaning. As a result of British Sugar and the two previous Court of Appeal decisions the word "consequential" has been given a meaning which (as Waller LJ pointed out) the courts must now assume businessmen intend when it is inserted into commercial contracts.

The British Sugar case is also a lesson to the draftsmen of commercial contracts to use the term "consequential loss" only with extreme care and with a full understanding of what is meant by the term in the legal sense. In light of the meaning given to the term by the Court of Appeal it is difficult to envisage circumstances in which a supplier would wish to include it in a clause seeking to define loss for which the supplier does not assume responsibility. It is submitted that "consequential loss" as defined by the Court of Appeal is probably not going to be recoverable under the rule in Hadley v Baxendale anyway and therefore suppliers, by including the term in clauses in their contracts seeking to exclude or limit liability, are not really limiting their liability at all. As a result, if they are later in breach of contract, they could very well end up paying for consequences which are more than they thought they bargained for.

The safe course is to spell out clearly in the contract documents, whether they take the form of standard terms and conditions, or the form of a document which is being negotiated, exactly what type of loss is being excluded. If the aim is to exclude loss of profit then the contract should say so. It is much better to have the various heads of loss in respect of which liability is either to be excluded or limited clearly spelled out rather than to leave things to chance and end up arguing in court about what type of loss is properly classified as "consequential". 